\title{
The composition of a bioprocessed shiitake (Lentinus edodes) mushroom mycelia and rice bran formulation and its antimicrobial effects against Salmonella enterica subsp. enterica serovar Typhimurium strain SL1344 in macrophage cells and in mice
}

\author{
Sung Phil Kim ${ }^{1,2}$, Sang Jong Lee ${ }^{2}$, Seok Hyun $\mathrm{Nam}^{3^{*}}$ and Mendel Friedman ${ }^{4^{*}}$ (D)
}

\begin{abstract}
Background: Human infection by pathogenic Salmonella bacteria can be acquired by consuming of undercooked meat products and eggs. Antimicrobial resistance against antibiotics used in medicine is also a major concern. To help overcome these harmful effects on microbial food safety and human health, we are developing novel antimicrobial food-compatible formulations, one of which is described in the present study.

Methods: The composition of a bioprocessed (fermented) rice bran extract (BPRBE) from Lentinus edodes liquid mycelia culture was evaluated using gas chromatography and mass spectrometry, and the mechanism of its antibacterial effect against Salmonella Typhimurium, strain SL1344 was investigated in macrophage cells and in mice.

Results: BPRBE stimulated uptake of the bacteria into RAW 264.7 murine macrophage cells. Activation of the cells was confirmed by increases in NO production resulting from the elevation of inducible nitric oxide synthase (iNOS) mRNA, and in protein expression. Salmonella infection down-regulated the expression of the following protein biomarkers of autophagy (a catabolic process for stress adaptation of cellular components): Beclin-1, Atg5, Atg12, Atg16, LC3-I and LC3-II. BPRBE promoted the upregulation of protein expressions that induced bacterial destruction in autolysosomes of RAW 264.7 cells. ELISA analysis of interferon IFN- $\beta$ showed that inflammatory cytokine secretion and bactericidal activity had similar profiles, suggesting that BPRBE enhances cell-autonomous and systemic bactericidal activities via autophagic capture of Salmonella. The treatment also elicited increased excretion of bacteria in feces and their decreased translocation to internal organs (cecum, mesenteric lymph node, spleen, and liver).

Conclusions: The antibiotic mechanism of BPRBE involves the phagocytosis of extracellular bacteria, autophagic capture of intracellular bacteria, and prevention of translocation of bacteria across the intestinal epithelial cells. The new bioprocessing combination of mushroom mycelia and rice brans forms a potentially novel food formulation with in vivo antimicrobial properties that could serve as a functional antimicrobial food and medical antibiotic.
\end{abstract}

Keywords: Novel food formulation, Antimicrobial food, Salmonellosis, Autophagy, Phagocytosis

\footnotetext{
*Correspondence: shnam@ajou.ac.kr; mendel.friedman@ars.usda.gov

${ }^{3}$ Department of Biological Science, Ajou University, Suwon 16499, Republic

of Korea

${ }^{4}$ Western Regional Research Center, Agricultural Research Service, U.S.

Department of Agriculture, Albany, CA 94710, USA

Full list of author information is available at the end of the article
}

(c) The Author(s). 2018 Open Access This article is distributed under the terms of the Creative Commons Attribution 4.0 International License (http://creativecommons.org/licenses/by/4.0/), which permits unrestricted use, distribution, and reproduction in any medium, provided you give appropriate credit to the original author(s) and the source, provide a link to the Creative Commons license, and indicate if changes were made. The Creative Commons Public Domain Dedication waiver (http://creativecommons.org/publicdomain/zero/1.0/) applies to the data made available in this article, unless otherwise stated. 


\section{Background}

Salmonella serotypes are reported to be the leading cause of foodborne disease outbreaks in the United States [1]. Rice plants produce bioactive rice brans and hulls, and mushrooms produce bioactive polysaccharides and other compounds. These food components have been reported to have numerous potential health benefits in cells, rodents, and humans, reviewed by Friedman [2-4]. The exposure of mushroom mycelia and rice bran to bioprocessing seems to result in the production of new bioactive compounds not present in the same combination that has not been bioprocessed. Our previously published studies have investigated the properties of rice hull smoke, rice brans, and bioprocessed (fermented) mushroom mycelia with added black rice bran, turmeric, and elm tree bark and will be briefly described here.

We previously reported that a liquid rice hull smoke extracts prepared by pyrolysis of rice hulls and liquefaction of the smoke [5] inactivated antibiotic-resistant Salmonella Typhimurium strains [6, 7] and protected mice against diabetes [8, 9], endotoxemia [10], and obesity [11]. We also reported that rice brans and their bioactive component $\gamma$-oryzanol protected mice and exhibited anti-allergic [12,13] and anticarcinogenic properties in cells and in mice [14-18]. In other studies we showed that bioprocessed mushroom mycelia containing black rice bran [19], or turmeric [20] protected mice against salmonellosis; and a polysaccharide isolated from a liquid culture of mushroom mycelia containing black rice bran protected mice against endotoxemia [21]. In addition, mushroom mycelia bioprocessed with elm tree bark protected mice against allergic asthma [22].

The main objective of the present study was to elucidate the mechanisms that seem to govern the inactivation of foodborne Salmonella Typhimurium pathogenic bacteria by extracts of bioprocessed mushroom mycelia with added rice bran in murine macrophage cells and in mice and to relate the composition of the extracts, as determined using gas chromatography/mass spectrometry (GS/MS), to their inhibitory activity.

\section{Methods}

\section{Materials}

RPML-1640 medium (DMEM), phosphate-buffered saline (PBS), fetal bovine serum (FBS), and other cell culture reagents were purchased from Hyclone Laboratories (Logan, UT, USA). Potato dextrose agar medium (PDA), nutrient agar (NA) and MacConkey agar medium were the products from Difco Laboratory (Detroit, MI, USA). 3-(4,5Dimethylthiazol-2-yl)-2,5-diphenyl tetrazolium bromide, MTT and other analytical grade reagents were obtained from Sigma-Aldrich (St. Louis, MO, USA).

\section{Preparation of bioprocessed rice bran extract (BPRBE)}

The genetic identity of Lentinus edodes was confirmed by the Korean Center of Microorganisms (Seoul, Korea). Cultivation of the Lentinus edodes mushrooms and the bioprocessing of rice bran with added fungal mycelia were conducted according to our previously reported method [21, 22]. Briefly, the main liquid medium (3 L) containing rice bran $(20 \mathrm{~g} / \mathrm{L})$ and dried soybean powder ( $2 \mathrm{~g} / \mathrm{L})$ was inoculated with the inoculum (10\%) culture mycelia. The main liquid culture was then bioprocessed using $5 \mathrm{~L}$ fermenter at $28{ }^{\circ} \mathrm{C}$ and $150 \mathrm{rpm}$. After 7 days, the culture mass was ground in a colloid mill and the powder was then treated with $0.1 \mathrm{M}$ lactic acid for $60 \mathrm{~min}$, followed by treatment with an enzyme mixture for cell wall lysis. The acid- and enzyme-treated culture mass was then extracted with hot water at $90{ }^{\circ} \mathrm{C}$ and freeze-dried to a solid material. Non-bioprocessed rice bran extract (NPRBE), not subjected to the fungal mycelia fermentation but subjected to the acid and enzyme treatments, was used as a control formulation.

\section{Component analysis by GC-MS}

The dried extracts from above were derivatized using previously published methods [22, 23]. Briefly, samples were reacted at $60{ }^{\circ} \mathrm{C}$ for $1 \mathrm{~h}$ with $100 \mu \mathrm{L}$ of methoxyamine hydrochloride in pyridine $(20 \mu \mathrm{L} / \mathrm{mL})$. The sample was then silylated with $100 \mu \mathrm{L}$ of $N$-methyl- $N$-trimethylsilyltrifluoroacetamide (MSTFA) $\left(70{ }^{\circ} \mathrm{C} / 1 \mathrm{~h}\right)$. GC/MS conditions were as follows: the gas chromatograph, model 6890GC (Agilent Technologies, Santa Clara, CA, USA) was equipped with a mass spectrometer detector 5975 and an apolar stationary-phase DB-1 column (100\% dimethylpolysiloxane); (30 m × $0.25 \mathrm{~mm}$; i.d. $0.25 \mu \mathrm{m}$ film thickness). The starting oven temperature of the column at the time of injection, $70{ }^{\circ} \mathrm{C}$, was maintained for $4 \mathrm{~min}$ and then ramped up at a rate of $10{ }^{\circ} \mathrm{C} / \mathrm{min}$ until it reached a final temperature of $300{ }^{\circ} \mathrm{C}$. The carrier gas (helium) had a flow rate of $1 \mathrm{~mL} / \mathrm{min}$. The injector and the detector were maintained at $250{ }^{\circ} \mathrm{C}$. Injection volume was $1 \mu \mathrm{L}$, after being split 25 to 1 . The mass spectrometer was set to electron ionization mode $(70 \mathrm{eV})$. Identification of components was by both retention time, and comparison of the mass spectra to a commercial library [24].

\section{Bacterial strain and culture conditions}

Salmonella enterica subsp. enterica serovar Typhimurium (S. Typhimurium) strain SL1344 was obtained from the National Collection of Type Cultures (Salisbury, Wiltshire, UK) and kept as frozen glycerol stock. The bacterial cell cultures were used as previously described [20].

\section{In vitro bactericidal assay}

The bactericidal effect against S. Typhimurium SL1344 in liquid culture was examined as follows: aliquots of BPRBE 
and NPRBE were added to $3 \mathrm{~mL}$ Salmonella culture to form three concentrations of BPRBE $(1,10$, and $100 \mu \mathrm{g} /$ $\mathrm{mL}$, respectively). The assay was performed using an inoculum size of Salmonella at $1 \times 10^{7}$ colony-forming units (CFU). These were then allowed to grow for $12 \mathrm{~h}$ at $37^{\circ} \mathrm{C}$ in nutrient broth. Cell growth profiles were determined spectrophotometrically by monitoring the turbidity of the culture at $600 \mathrm{~nm}$ at $2 \mathrm{~h}$ intervals for up to $8 \mathrm{~h}$ using a UV/VIS spectrophotometer (iMark ${ }^{\mathrm{Tm}}$, Bio-Rad, Hercules, CA, USA).

\section{Mammalian cell culture}

Murine RAW 264.7 macrophage cells were obtained from the American Type Culture Collection (Manassas, VA, USA). The cells were cultured in RPMI-1640 medium supplemented with $10 \%$ heat-inactivated FBS $(v / \mathrm{v}), 100 \mathrm{U} / \mathrm{mL}$ penicillin, and $100 \mu \mathrm{g} / \mathrm{mL}$ streptomycin. The cells were maintained at $37{ }^{\circ} \mathrm{C}$ with $5 \% \mathrm{CO}_{2}$ in a humidified atmosphere.

\section{Cell viability assay}

MTT staining as described by Mosmann [25], and previously used in this laboratory [22, 23], was used to evaluate the cytotoxicity of BPRBE and NPRBE. RAW 264.7 cells were seeded into 96 -well tissue culture plate at a density of $1 \times 10^{4}$ cells/well and cultured at $37^{\circ} \mathrm{C}$ in humidified air with $5 \% \mathrm{CO}_{2}$ for $16 \mathrm{~h}$. The cells were then treated with 3 concentrations of BPRBE and NPRBE (1, 10 , and $100 \mu \mathrm{g} / \mathrm{mL}$ ) for $48 \mathrm{~h}$ and stained with added MTT. Absorbance was read in a microplate reader (iMark, Bio-Rad, Hercules, CA, USA) at $570 \mathrm{~nm}$, with a reference wavelength of $655 \mathrm{~nm}$. Cell viability was expressed as the percentage of live cells relative to those in the control group treated with PBS.

\section{Nitric oxide (NO) generation assay}

Nitric oxide (NO) formation was measured by determining the concentration of its stable metabolite nitrite using a microplate assay as described by Murakami, et al. [26], a method previously used in this laboratory [23, 27]. RAW 264.7 cells $\left(1 \times 10^{5}\right.$ cells/well $)$ in a 96-well tissue culture plate were treated simultaneously with lipopolysaccharide (LPS; $100 \mathrm{ng} / \mathrm{mL}$ ) and either BPRBE or NPRBE at three concentrations $(1,10$ and $100 \mathrm{~g} / \mathrm{mL}$ each) for $48 \mathrm{~h}$. After incubation, the culture medium was mixed with an equal volume of Griess reagent (1\% sulfanilamide and $0.1 \% \mathrm{~N}$-[1-naphthyl] ethylenediamine dihydrochloride in $5 \%$ phosphoric acid) at room temperature for $15 \mathrm{~min}$. The absorbance was then measured at $570 \mathrm{~nm}$ using a microplate reader against a standard of sodium nitrite.

\section{Phagocytotic uptake assay}

To measure internalized bacteria in macrophages, RAW 264.7 cells were infected with the $S$. Typhimurium as described by $\mathrm{Lu}$, et al. [28]. To analyze the efficiency of bacterial uptake by macrophages, inoculum containing $1 \times$ $10^{4} \mathrm{CFU}$ was added to macrophage cells $\left(1 \times 10^{4}\right.$ cells $)$ pre-treated with three concentrations of BPRBE and $\operatorname{NPRBE}(1,10$, and $100 \mu \mathrm{g} / \mathrm{mL})$ for $4 \mathrm{~h}$, and then incubated for $60 \mathrm{~min}$ at $37^{\circ} \mathrm{C}$ in humidified air with $5 \% \mathrm{CO}_{2}$. Cells were washed once with RPMI-1640 medium after incubation and then treated to kill extracellular bacteria with the same medium containing 10\% FBS and gentamy$\operatorname{cin}(30 \mu \mathrm{g} / \mathrm{mL})$ for $30 \mathrm{~min}$. For viable cell counting, the infected macrophage cells were washed thrice and then lysed with sterile distilled water. Aliquots of lysates were then plated onto nutrient agar (NA) medium to measure CFUs. Phagocytosis efficiency of BPRBE and NPRBE was expressed as the fold increase of internalized bacteria relative to those without sample treatment.

\section{Measurement of interferon (IFN)- $\beta$}

After RAW 264.7 cells $\left(1 \times 10^{5}\right.$ cells $)$ pre-treated with BPRBE and NPRBE $(100 \mu \mathrm{g} / \mathrm{mL})$ for $24 \mathrm{~h}$ were subsequently infected with $S$. Typhimurium $\left(1 \times 10^{5} \mathrm{CFU}\right)$ for $5 \mathrm{~h}$, the cell-free culture medium was recovered and stored at $-20^{\circ} \mathrm{C}$ until use. IFN- $\beta$ release into the culture medium was measured using an ELISA kit (PBL Assay Science, Piscataway, NJ, USA). The absorbance of the reaction mixture at $420 \mathrm{~nm}$ was measured in a microplate reader.

\section{Gastroenteritis animal model}

Gastroenteritis was stimulated in test animals as described in a previous study [7]. Pathogen-free female Balb/c mice, aged 6 to 8 weeks, were purchased from Orient Bio Inc. (Seoul, Republic of Korea) and were hosted in a stainless-steel cage. Conditions were as follows: the light/ dark cycle repeated every $12 \mathrm{~h}$; the temperature was maintained at $20-22{ }^{\circ} \mathrm{C}$; and the relative humidity was maintained at $50 \pm 10 \%$. The mice were given free access to a pelleted commercial chow diet (catalog no. 5 L79; Orient Bio Inc.). Tap water was available ad libitum. After a one-week acclimation, mice were divided into control and experimental groups $(n=10)$, avoiding any intergroup difference in body weight. Test groups were administered BPRBE or NPRBE $(10 \mathrm{mg} / \mathrm{kg})$ via oral dietary intake for 2 wk. Gastroenteritis was stimulated in mice as described by Barthel, et al. [29]. Briefly, 4-h fasting mice were administered streptomycin $(20 \mathrm{mg}$ in $75 \mu \mathrm{L}$ water) by oral gavage. After $24 \mathrm{~h}$, diet and water were again withdrawn for $4 \mathrm{~h}$. Mice were then infected with $S$. Typhimurium strain SL1344 in $100 \mu \mathrm{L}$ PBS $\left(1 \times 10^{8}\right.$ CFUs $)$ by oral gavage. After an additional $2 \mathrm{~h}$ of fasting, food and water was offered. The mice were monitored for $48 \mathrm{~h}$ and then sacrificed by asphyxia with $\mathrm{CO}_{2}$ to remove organs. The 
protocol for the mouse studies was approved by the Ethics Committee for Animal Care and Use, Ajou University, Suwon, Republic of Korea.

\section{Determination of bacterial load in organs and feces}

Bacterial infection of the organs, and the presence in the feces, was determined as described in a previous study [7]. The cecum, mesenteric lymph node (MLN), spleen, and liver of the sacrificed animals were removed aseptically. The cecum was used after removing its content. The organs were weighed and then homogenized in $1 \mathrm{~mL}$ of sterile PBS with the aid of a tissue homogenizer maintained at $4{ }^{\circ} \mathrm{C}$. Diluents of the homogenates were processed to count MacConkey agar medium supplemented with streptomycin $(50 \mathrm{~g} / \mathrm{mL})$.

Fecal samples were collected at days 1-2 after gavage of $S$. Typhimurium in the mice from the Salmonella gastroenteritis model. The number of bacteria per gram of feces was determined as follows: Aliquots $(100 \mu \mathrm{L})$ of fecal suspensions were serially diluted in PBS and then plated on the streptomycin-supplemented MacConkey agar medium. Cells were counted following incubation overnight at $37^{\circ} \mathrm{C}$.

\section{Reverse transcription polymerase chain reaction (RT-PCR)} Total cellular RNA was extracted using an Acid Phenol GTC-chloroform method as described by Chomczynski and Sacchi [30], and previously employed in this laboratory $[22,23,27]$. For RT-PCR, total RNA $(1 \mu \mathrm{g})$ was incubated with AMV reverse transcriptase $(6 \mathrm{U})$ and oligo (dT18) as primer (100 ng). DNA amplification from the iNOS gene was then primed in a reaction mixture containing dNTP mix $(400 \mu \mathrm{M}), \mathrm{Taq}$ polymerase $(2.5 \mathrm{U})$ and primer set $(20 \mu \mathrm{M}$ each): sense primer, 5'ATGC CGAAGCAAACATCAC-3'; antisense primer, 5'-TAAT GTCCAGGAAGTAGGTG-3'. Amplification was conducted in a thermocycler (PTC-200, MJ Research Inc., Reno, NV, USA) using the following program: one cycle for $5 \mathrm{~min}$ at $94{ }^{\circ} \mathrm{C}, 30$ cycles for $30 \mathrm{~s}$ at $94{ }^{\circ} \mathrm{C}, 45 \mathrm{~s}$ at $58{ }^{\circ} \mathrm{C}$, and $45 \mathrm{~s}$ at $72{ }^{\circ} \mathrm{C}$, and finally one cycle for $5 \mathrm{~min}$ at $72{ }^{\circ} \mathrm{C}$. The DNA was then fractionated with agarose gel electrophoresis and quantified using a gel documentation system (model LAS-100CH, Fuji Photo Film Co., Tokyo, Japan).

\section{Antibodies}

Western blot analyses were performed using the following antibodies: rabbit anti-mouse iNOS polyclonal antibody from Santa Cruz (Dallas, TX, USA) and mouse anti-Actin monoclonal antibody from Millipore Corp. (Billerica, MA, USA), and all rabbit monoclonal antibodies raised against Beclin-1, Atg5, Atg12, Atg16L, LC3A/B, and phosphoIRF-3 from Cell Signaling Tech. (Danvers, MA, USA).

\section{Western blot analysis}

The Western Blot technique was the same as described in previous studies [22, 23]. The BPRBE- and NPRBE-treated RAW 264.7 cells were lysed to extract total cellular proteins using RIPA buffer $(50 \mathrm{mM}$ Tris $\mathrm{Cl}, 150 \mathrm{mM} \mathrm{NaCl}$, 15 NP-40, 0.5\% sodium deoxycholate, $0.1 \%$ SDS and 1 mM EDTA, pH 7.4). Protein was quantified using a Bio-protein Kit (Bio-Rad) with bovine serum albumin (BSA) as a standard. Proteins from the cell extract $(30 \mu \mathrm{g})$ were separated on $10 \%$ SDS-polyacrylamide gels and electrophoretically transferred onto the Millipore nitrocellulose membrane. After blocking with 5\% skim milk, the membrane was incubated with primary antibodies to react for at least $3 \mathrm{~h}$. The secondary antibody reaction with HRP-conjugated anti-IgG antibody was then performed under the same conditions. Blots were developed using the ELC detection kit (Pierce, Rockford, IL, USA). Quantification was achieved using a gel documentation system (model LAS-100CH, Fuji Photo Film Co., Tokyo, Japan).

\section{Statistical analysis}

Analyses were run in triplicate, and expressed as the mean \pm SD. Significant differences between means were determined by the ANOVA followed by Tukey's test using the Statistical Analysis Software package SAS (Cary, NC, USA). $p<0.05$ is regarded as significant.

\section{Results}

The composition of BPRBE and NPRBE

GC/MS analysis revealed that the two extracts contained 45 characterized compounds (Table 1). Some components remained unidentified, and others were tentatively identified. Among the identified compounds, 25 compounds were found solely in BPRBE and 13 structurally different compounds were only in NPRBE; seven compounds were present in both BPRBE and NPRBE. These results suggest that bioprocessing induces the formation of new compounds, probably catalyzed by enzymes present in the fungal mycelia. These compounds might be responsible for any observed antimicrobial activity of BPRBE.

BPRBE is not bactericidal against Salmonella in PBS buffer To find out if the extract has bactericidal activity against $S$. Typhimurium, the bacteria were incubated with serially diluted BPRBE in PBS $(1,10$, and $100 \mu \mathrm{g} / \mathrm{mL})$ at $37^{\circ} \mathrm{C}$ for 0 , $2,4,6$, and $8 \mathrm{~h}$. Fig. 1 shows that that there was no significant bactericidal activity up to 8 -h of incubation. The data demonstrate that BPRBE did not kill the bacteria directly. We previously observed a similar lack of bactericidal activity in vitro by a polysaccharide isolated from a black rice bran extract bioprocessed with mushroom mycelia [19].

Because the chemical nature of the identified compounds shown in Table 1 varied widely, it is difficult to 
Table 1 Compounds identified by GC/MS analysis of NPRBE and BPRBE

\begin{tabular}{|c|c|c|c|c|}
\hline Peak & R.T. (min.) & Compounds & NPRBE & BPRBE \\
\hline 1 & 9.0 & Propionic acid & - & 1.76 \\
\hline 2 & 10.0 & L-Valine & - & 0.06 \\
\hline 3 & 10.4 & $\begin{array}{l}\text { 1-(3-Methylbutyl)-2,3,4,6- } \\
\text { tetramethylbenzene }\end{array}$ & 0.29 & - \\
\hline 4 & 12.2 & L-Leucine & - & 0.14 \\
\hline 5 & 12.4 & Butanoic acid & - & 0.16 \\
\hline 6 & 15.7 & Cadaverine & - & 0.06 \\
\hline 7 & 16.0 & Glycerol & 6.29 & 2.57 \\
\hline 8 & 16.8 & Glycine & - & 0.07 \\
\hline 9 & 17.2 & Butanedioic acid & - & 0.43 \\
\hline 10 & 17.8 & Pyrimidine & - & 0.05 \\
\hline 11 & 18.3 & Fumaric acid & - & 0.05 \\
\hline 12 & 19.6 & Hydroquinone & - & 0.02 \\
\hline 13 & 20.3 & L-Aspartic acid & 0.11 & - \\
\hline 14 & 22.1 & Hexadecane & - & 0.08 \\
\hline 15 & 22.6 & Erythritol & - & 0.26 \\
\hline 16 & 22.6 & D-(+)-Arabitol & 0.04 & - \\
\hline 17 & 22.8 & Proline & 0.07 & 0.07 \\
\hline 18 & 22.9 & L-Aspartic acid & 0.02 & - \\
\hline 19 & 23.4 & $\begin{array}{l}\text { Methyl 2-amino-4-(2-aminophenyl)- } \\
\text { 4-oxobutanoate }\end{array}$ & - & 0.11 \\
\hline 20 & 24.2 & 3-Pyridinecarboxylic acid & - & 0.10 \\
\hline 21 & 25.6 & Xylonic acid & - & 0.06 \\
\hline 22 & 26.4 & D-Glucose & 0.17 & 0.09 \\
\hline 23 & 26.7 & D-Xylose & - & 0.59 \\
\hline 24 & 27.7 & Xylitol & 0.07 & - \\
\hline 25 & 28.7 & Phosphoric acid & 0.35 & - \\
\hline 26 & 29.5 & Azelaic acid & 0.08 & - \\
\hline 27 & 30.0 & Citric acid & 0.21 & - \\
\hline 28 & 30.6 & D-Glucuronic acid & 0.06 & - \\
\hline 29 & 31.3 & Ribitol & - & 0.28 \\
\hline 30 & 31.3 & D-(+)-Gluconic acid & 0.05 & - \\
\hline 31 & 31.56 & D-Glucose & 0.18 & - \\
\hline 32 & 31.63 & D-Galactose & - & 55.51 \\
\hline 33 & 32.0 & D-Mannose & - & 10.08 \\
\hline 34 & 32.4 & D-Mannitol & 0.05 & - \\
\hline 35 & 32.8 & Gluconic acid, 1,4-lactone & - & 0.18 \\
\hline 36 & 33.7 & D-Gluconic acid & 0.25 & - \\
\hline 37 & 34.3 & Glucopyranose & & 0.76 \\
\hline 38 & 34.7 & Hexadecanoic acid & 0.07 & 0.09 \\
\hline 39 & 35.4 & Myo-inositol & 0.52 & 0.44 \\
\hline 40 & 38.4 & Stearic acid & 0.03 & 0.05 \\
\hline
\end{tabular}

Table 1 Compounds identified by GC/MS analysis of NPRBE and BPRBE (Continued)

\begin{tabular}{lllll}
\hline Peak & R.T. (min.) & Compounds & NPRBE & BPRBE \\
\hline 41 & 39.4 & 2-O-Glycerol-a-d-galactopyran & 0.14 \\
42 & 41.8 & Nonanol & 0.02 \\
43 & 44.9 & Sucrose & 86.42 & 0.40 \\
44 & 46.5 & $\begin{array}{l}\text { [4-Bromo-2-2-hysrazono } \\
\text {-phenyl-methyl)-phenyl] }\end{array}$ & 13.32 \\
& & -carbamic acid, ethyl ester- & \\
45 & 46.7 & Maltose & 0.13
\end{tabular}

$\overline{B P R B E}$ bioprocessed rice bran extract, NPRBE non-processed rice bran extract

determine which compound or combination of compounds might be responsible for the bioactivity of BPRBE. This aspect merits further study.

Effects of BPRBE on phagocyte activation and cell survival To examine whether BPRBE can enhance cell-mediated immune function, RAW 264.7 murine macrophage cells were cultivated in the presence of the extracts, and the resultant NO production was then assessed as an indicator of macrophage activation. Table 2 shows that BPRBE (1, 10 , and $100 \mu \mathrm{g} / \mathrm{mL}$ ) markedly induced NO production in a dose- dependent manner. The NO formation levels of BPRBE at $10 \mu \mathrm{g} / \mathrm{mL}$ or higher doses were significantly higher than that obtained with lipopolysaccharide (LPS) $(100 \mathrm{ng} / \mathrm{mL})$. By contrast, NPRBE used as internal control barely induced NO production relative to the vehicle.

RT-PCR was used to confirm BPRBE-induced NO production at the gene expression level. Fig. 2a shows that the mRNA expression level from the iNOS gene of Salmonella-infected cells pre-treated with BPRBE was 1.9-fold higher than that in the bacteria infected cells without treatment by the extract. Western blot analysis

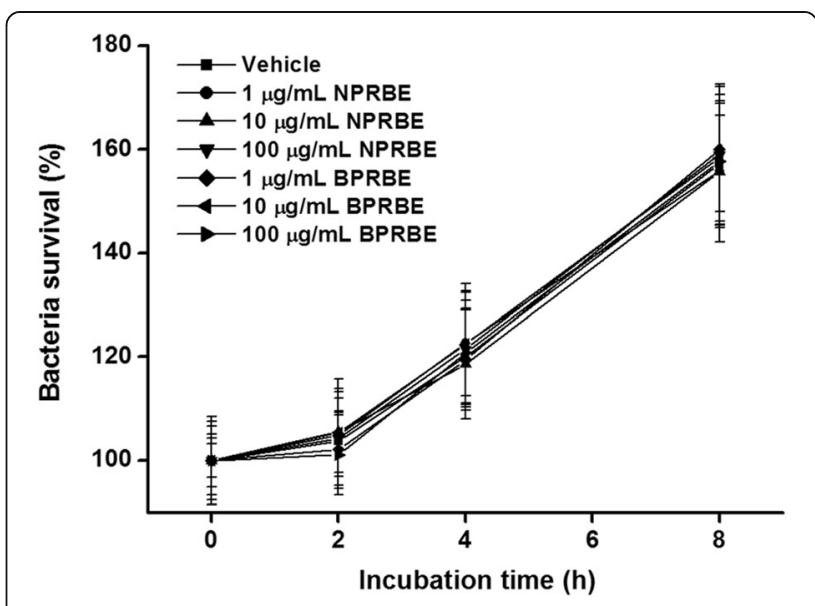

Fig. 1 Effects of BPRBE and NPRBE on growth of S. Typhimurium. Serially diluted BPRBE and NPRBE $(1,10$, and $100 \mu \mathrm{g} / \mathrm{mL})$ were incubated with $\mathrm{S}$. Typhimurium $\left(2 \times 10^{4} \mathrm{CFU}\right)$ for $2,4,6$, and $8 \mathrm{~h}$. Plotted values are mean \pm SD of triplicate experiments 
Table 2 Effects of NPRBE and BPRBE on macrophage activation and survival

\begin{tabular}{lll}
\hline Sample & Nitrite $(\mu \mathrm{M})$ & Cell viability (\%) \\
\hline Vehicle & $2.02 \pm 0.20^{\mathrm{f}}$ & $100.0 \pm 1.8^{\mathrm{a}}$ \\
LPS & $31.13 \pm 0.34^{\mathrm{c}}$ & - \\
NPRBE $(\mu \mathrm{g} / \mathrm{mL})$ & & \\
$\quad 1$ & $1.80 \pm 0.20^{\mathrm{f}}$ & $102.3 \pm 2.8^{\mathrm{a}}$ \\
10 & $1.75 \pm 0.60^{\mathrm{f}}$ & $102.9 \pm 2.2^{\mathrm{a}}$ \\
100 & $6.91 \pm 0.67^{\mathrm{e}}$ & $102.7 \pm 2.9^{\mathrm{a}}$ \\
BPRBE $(\mu \mathrm{g} / \mathrm{mL})$ & & \\
1 & $23.62 \pm 0.56^{\mathrm{d}}$ & $103.6 \pm 3.4^{\mathrm{a}}$ \\
10 & $34.4 \pm 1.2^{\mathrm{b}}$ & $102.5 \pm 1.7^{\mathrm{a}}$ \\
100 & $39.3 \pm 1.2^{\mathrm{a}}$ & $100.3 \pm 2.5^{\mathrm{a}}$ \\
\hline
\end{tabular}

Data are expressed as the mean \pm SD $(n=3)$. Values in each column with the same letter are not significantly different between groups at $p<0.05$. BPRBE, bioprocessed rice bran extract; NPRBE, non-processed rice bran extract

also shows that the iNOS protein expression profile was similar to that of mRNA expression (Fig. 2b). These data indicate that bioprocessing induces the activation of immune function in the macrophages.

Next, the cytotoxicity of the BPRBE treatments on RAW 264.7 cells was evaluated using the MTT assay. The results show that at three doses, survival rates of the BPRBE- and NPRBE-treated cells were not statistically different from those of the vehicle-treated control, indicating that BPRBE was not toxic to cells.

\section{Effects of BPRBE on the stimulation of phagocytosis}

To examine if BPRBE indirectly exerts bactericidal activity through phagocytosis, RAW 264.7 cells pre-treated with BPRBE at three doses were infected with $S$. Typhimurium SL1344 bacteria, followed by cell lysis and enumeration of their content. Fig. 3 shows that internalization of Salmonella into the macrophage cells was increased by the BPRBE treatment in a dose-dependent manner. The Salmonella internalization rates in the macrophages treated with 1,10 and $100 \mu \mathrm{g} / \mathrm{mL}$ BPRBE for $4 \mathrm{~h}$ were about 1.3-, 2.3-, and 3.4-fold greater than the rate with the vehicle-treated control. By contrast, NPRBE failed to increase the bacterial internalization at a significant level, even at the highest concentration of $100 \mu \mathrm{g} / \mathrm{mL}$. These results indicate that the bioprocessing of rice bran with a mushroom mycelia culture induces bactericidal activity in the macrophage cells by enhancing their phagocytic potential in a dose-dependent manner. These results are similar to the observations by Kim, et al. [31] on the antibacterial activity of the natural herb Houttuynia cordata on Salmonella within RAW 264.7 macrophage cells.

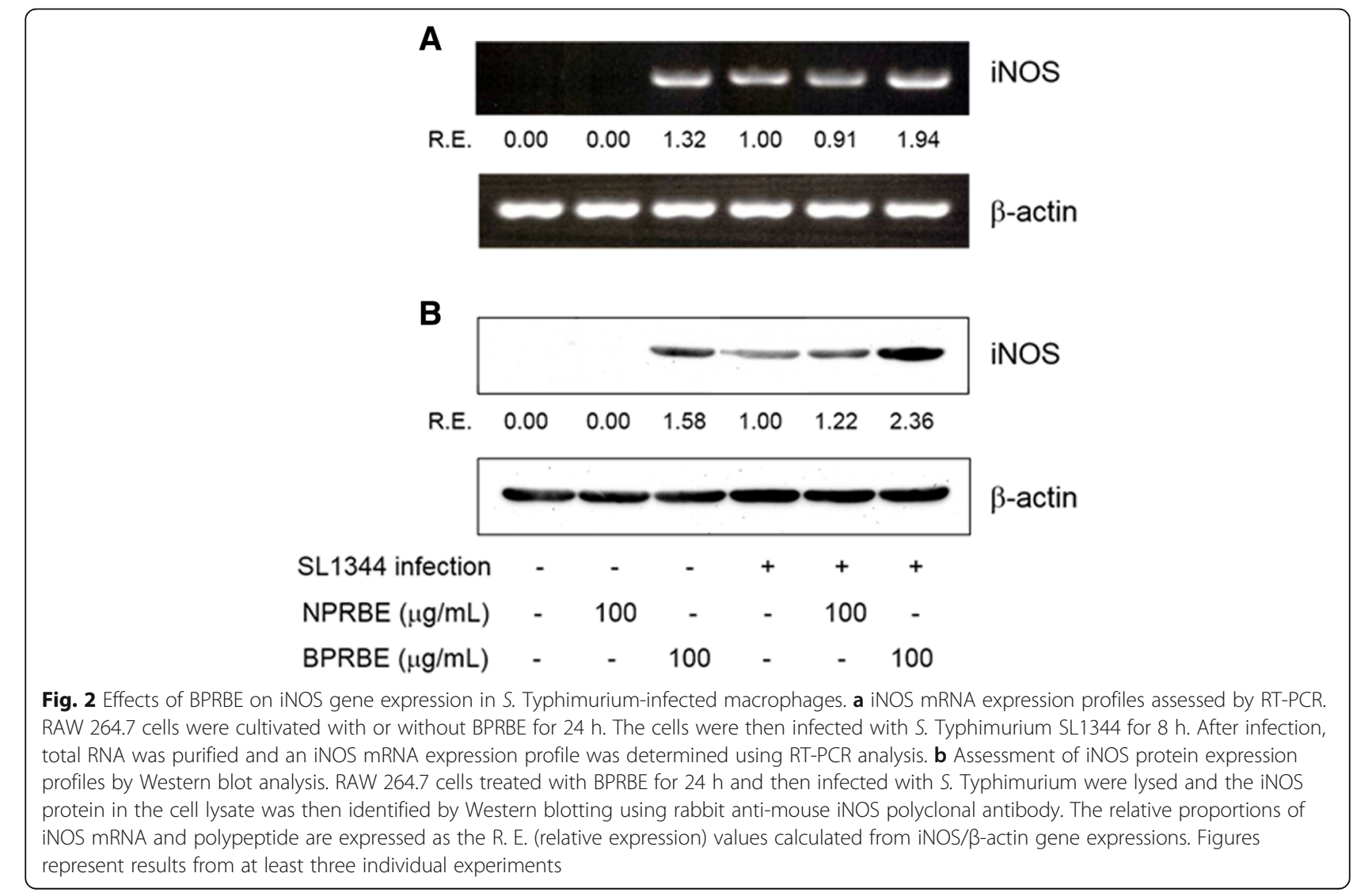




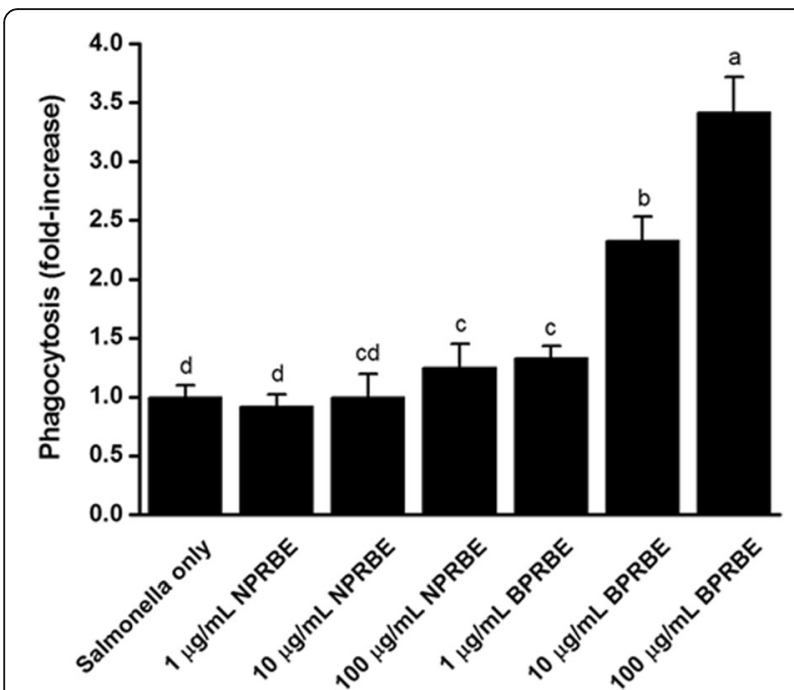

Fig. 3 Dose-dependent change in the phagocytotic effects of BPRBE on S. Typhimurium-infected macrophages. RAW 264.7 cells $\left(1 \times 10^{4}\right.$ cells) were incubated with three concentrations of BPRBE and NPRBE $(1,10$ and $100 \mu \mathrm{g} / \mathrm{mL})$ for $4 \mathrm{~h}$ and were then infected with $\mathrm{S}$. Typhimurium SL1344 ( $1 \times 10^{4}$ CFU). After incubation for $60 \mathrm{~min}$, bacteria-infected macrophages were cultivated in the presence of gentamycin $(30 \mu \mathrm{g} / \mathrm{mL}$ ) for $30 \mathrm{~min}$. Bacterial internalization efficiency was determined by measuring the protection of internalized bacteria against bactericidal action of the antibiotic gentamycin. Data are expressed as the mean \pm SD of triplicate experiments. Bars sharing a common letter are not significantly different between groups at $p<0.05$

\section{Effect of BPRBE on autophagy}

Many intracellular pathogens including Salmonella have evolved strategies that suppress autophagy, or evade autophagic recognition, leading to intracellular bacterial replication in a Salmonella-containing vehicle (SCV). The following experiments were carried out to determine if BPRBE can enhance autophagy in RAW 264.7 cells. The expression of Beclin-1, Atg5, Atg12, Atg16L proteins, microtubule-associated (LC3-I), and membrane-associated (LC3-II) light chain 3, which are needed for autophagic vacuole formation, phagophore membrane elongation, and autophagosome formation, respectively, were assessed in uninfected and Salmonella-infected RAW 264.7 cells in the absence or presence of BPRBE using Western blot analysis. The results show that Salmonella infection down-regulated expression of the autophagy-related proteins including Beclin-1 compared with the uninfected controls (Fig. 4). However, the BPRBE treatment up-regulated the expression of these autophagy-related proteins regardless of bacterial infection. These results indicate that the BPRBE treatment might block the escape of Salmonella from autophagy by the up-regulation of the expression of proteins involved in the assembly of the autophagic machinery, leading to cell-autonomous bactericidal action, i.e. direct bacterial destruction in the autolysosomes [32].
The effect of BPRBE on IFN- $\beta$ production

The autophagic capture of Salmonella is known to enhance not only cell-autonomous bactericidal action, but also systemic mechanisms of bacterial killing initiated by type I interferon production. It has been shown that the release of bacterial degradation products leads to activation of endosomal Toll-like receptors (TLRs), which produce IFN- $\beta$ through the activation of the interferon regulatory transcription factor IRF-3 [33]. Therefore, to determine whether the BPRBE treatment can enhance IFN- $\beta$ production via activation of the IRF-3-mediated signaling pathway in Salmonella-infected RAW 264.7 cells, IFN- $\beta$ release and IRF-3 activation were assessed by ELSA and Western blot analysis. Fig. 5 shows that the BPRBE treatment markedly induced phosphorylation of IRF-3 leading to the concomitant production of IFN- $\beta$ in the Salmonella-infected cells. In contrast, the NPRBE treatment failed to elicit both IRF-3 activation and IFN- $\beta$ production. These results show that BPRBE can restore the systemic bactericidal mechanism to normal status in terms of IFN- $\beta$ production from a suppressed level by blockading the escape of the infected bacteria from autophagic recognition.

\section{The effects of BPRBE on bacterial translocation to internal organs}

An in vivo assay using gastroenteritis model mice was used to examine if dietary administration of BPRBE suppresses the translocation of $S$. Typhimurium to internal organs through the intestinal epithelial barrier. Table 3 shows that the number of bacteria excreted in the feces increased 1.7- to 2-fold with BPRBE relative to the control on day 1 or 2 after infection with $S$. Typhimurium. Additional experiments on the translocation of $S$. Typhimurium to internal organs of infected mice show that BPRBE administration reduced bacterial load in the cecum, mesenteric lymph node, spleen, and liver 2 days after infection by $\sim 56,75,94$, and $88 \%$, respectively. NPRBE showed only insignificant effects on bacterial translocation to the organs compared with the control. These results suggest that BPRBE can suppress the translocation of $S$. Typhimurium to internal organs through the intestinal epithelial cell barrier, and, in parallel, enhance autophagy-mediated cell-autonomous and systemic bactericidal action, thus limiting orally infected $S$. Typhimurium dissemination from the intestine to several organs.

\section{Discussion}

The results of the present study show that the new food formulation produced by bioprocessing (fermenting) a mushroom mycelia culture supplemented with rice bran contains bioactive compounds not present in the same combination of mycelia and rice bran that was not bioprocessed. It is likely that the presence of certain 


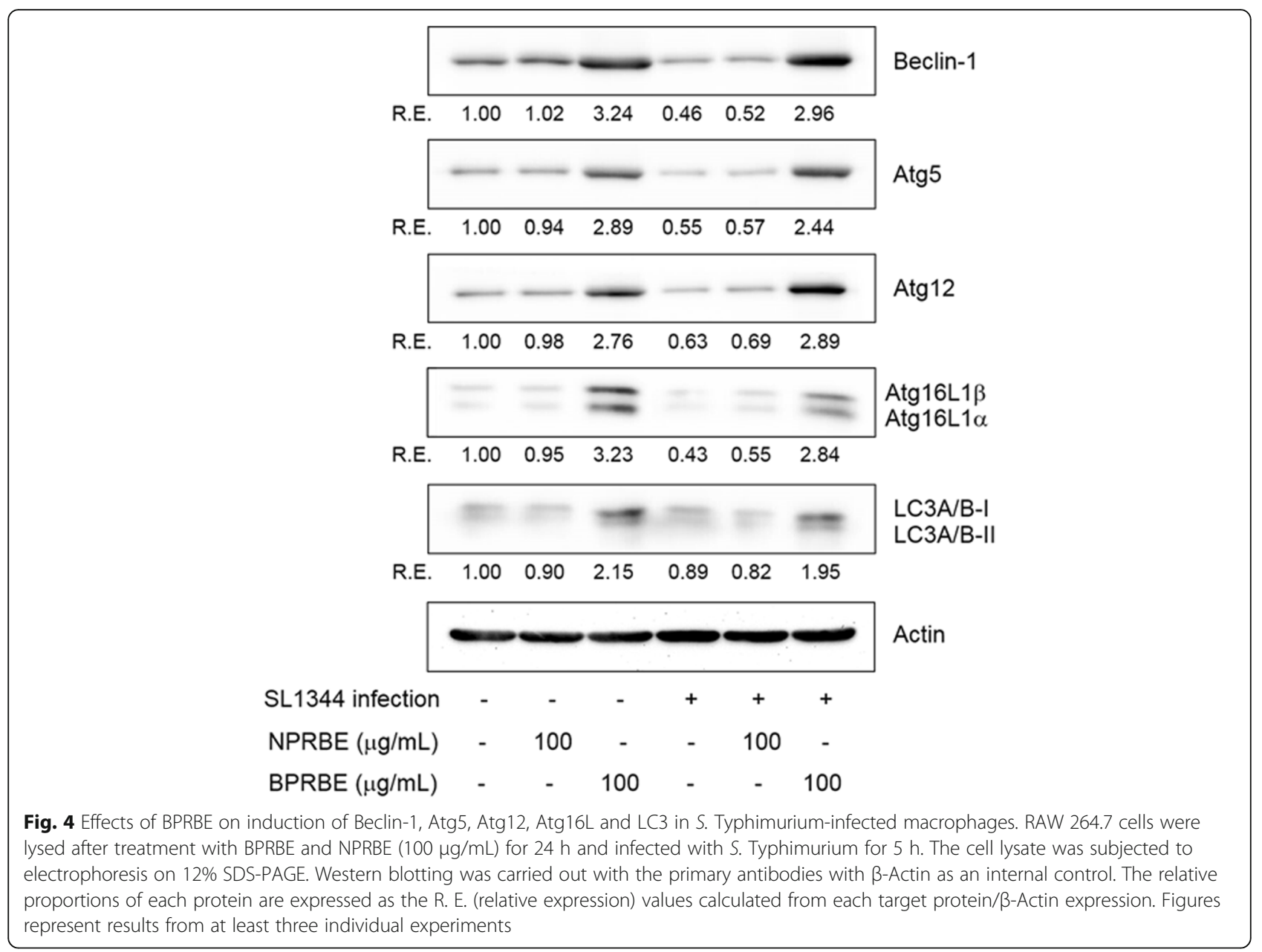

enzymes in the culture catalyze the formation of the new compounds. Although extracts of the bioprocessed product did not inhibit the growth of Salmonella in an in vitro bactericidal assay in laboratory media, they did inhibit the growth of the pathogen in infected macrophage cells and in different mouse organs (cecum, mesenteric lymph node, spleen, and liver). Because previous studies showed that lipopolysaccharides (LPS) induce autophagy in hepatocytes in vitro and in rodents, it is possible that polysaccharides produced during the described fermentation process might be the active autophagic compounds [34-37]. However, we do not have specific evidence for this suggestion.

These results complement and extend our findings with similarly bioprocessed combinations of mushroom mycelia with turmeric [20] and elm tree bark [22]. The practical value of this approach is reinforced by the related observation by Han, et al. [38] that a bioprocessed polysaccharide from Lentinus edodes mycelia liquid culture with added turmeric protected chicks from a lethal challenge of Salmonella
Gallinarum, suggesting that the formulation has the potential to serve as an antimicrobial livestock feed and possibly also as an antibiotic functional food in human diets.

The effect of the bioprocessed extract on the phagocytic response to bacterial infection has been investigated here, and the importance of autophagy in response to pathogens has been well documented, as indicated by the following selected observations. Yu, et al. [39] describe autophagy (self-eating in Greek) as a process whereby a double-membrane structure (autophagosome) engulfs unnecessary cytosolic proteins, organelles and invading pathogens and delivers them to the lysosome for enzymatic degradation. These authors reported that the depletion of autophagy components significantly reduced the replication of cytosolic Salmonella in Hela human epithelial cells. A study by Liang, et al. [40] shows that a Beclin-1 autophagy protein complex induces innate immune responses essential for eliminating pathogens. Kim, et al. [41] discusses how host cell autophagy orchestrates successful antimicrobial response in mycobacteria to antibiotics [41] and Wang, et al. [42] discuss how autophagy has been demonstrated to be 

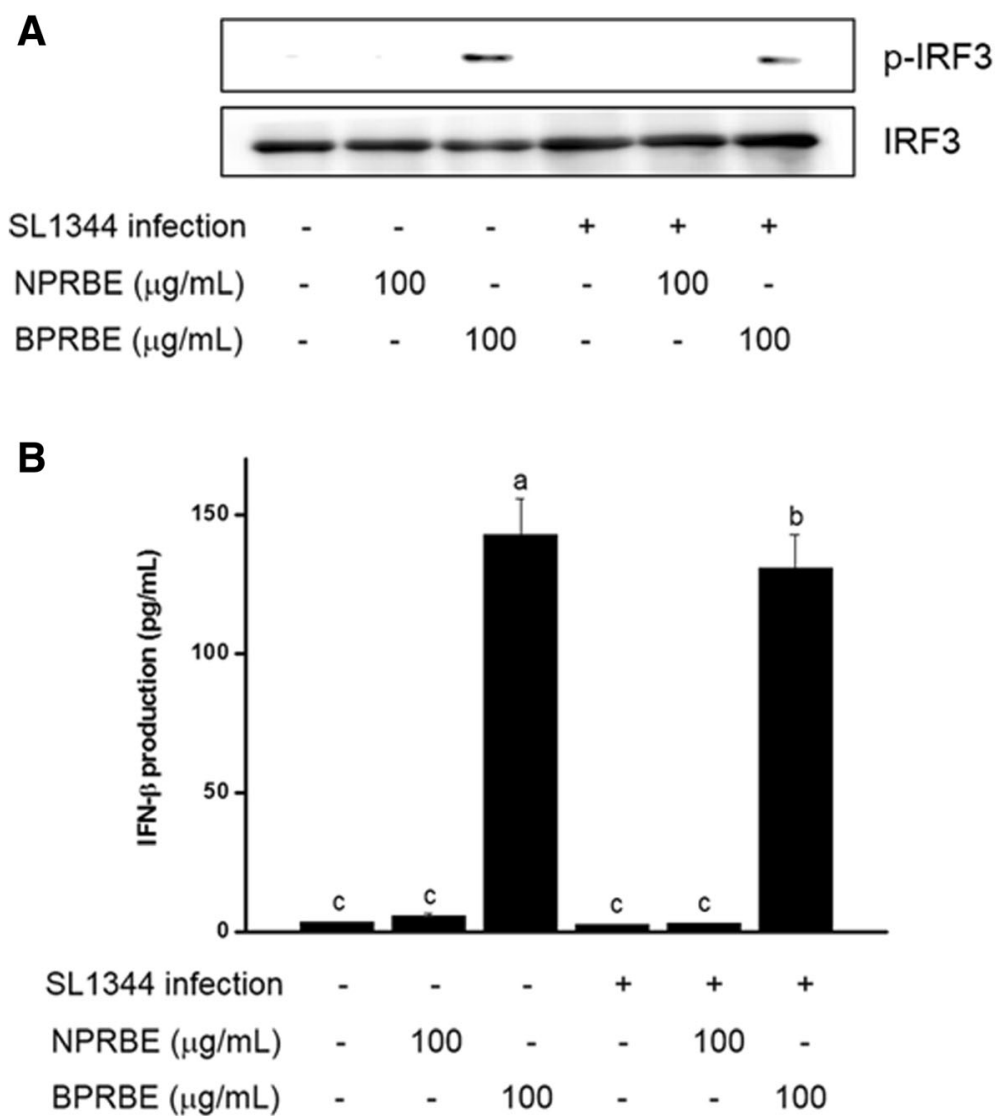

Fig. 5 Effects of BPRBE on induction of IFN- $\beta$ production through IRF3 activation in S. Typhimurium-infected macrophages. a Phospho-IRF3 protein (p-IRF3) expression profiles assessed by Western blot analysis. RAW 264.7 cells $\left(1 \times 10^{5}\right)$ were treated with BPRBE and NPRBE for $24 \mathrm{~h}$ and infected with S. Typhimurium and lysed. The phospho-form of IRF3 in the cell lysates was identified using Western blotting. $\mathbf{b}$ IFN- $\beta$ release from S. Typhimurium-infected macrophages pre-treated with BPRBE and NPRBE was determined using an ELISA kit. Data are expressed as the mean \pm SD of triplicate experiments. Bars sharing a common letter are not significantly different at $p<0.05$

an important defense mechanism to clear intracellular pathogenic organisms and as a process that regulates immune responses.

Bernal-Bayard and Ramos-Morales [43] review relevant studies on the molecular mechanisms used by Salmonella to evade the immune system by manipulating inflammatory pathways, Barakat and Friedman [44] describe the complex mechanism of autophagy in prostate cancer cells, and Nakahira, et al. [45] discuss the role of autophagy in the pathogenesis of lung diseases. These observations suggest that further investigation might focus on whether the mushroom mycelia-rice bran

Table 3 Effect of NPRBE and BPRBE on bacterial load in feces and organs from Salmonella-infected mice

\begin{tabular}{|c|c|c|c|}
\hline & \multicolumn{3}{|l|}{ Treatment } \\
\hline & Salmonella infection only & NPRBE (10 mg/kg) & BPRBE $(10 \mathrm{mg} / \mathrm{kg})$ \\
\hline \multicolumn{4}{|l|}{ Salmonella in feces $\left(\times 10^{5}\right.$ CFU/g) } \\
\hline 1 day & $338 \pm 18^{b}$ & $347 \pm 21^{b}$ & $662 \pm 48^{\mathrm{a}}$ \\
\hline 2 day & $420 \pm 31^{b}$ & $448 \pm 35^{\mathrm{b}}$ & $729 \pm 53^{\mathrm{a}}$ \\
\hline \multicolumn{4}{|l|}{ Salmonella in organs } \\
\hline Cecum $\left(\times 10^{5} \mathrm{CFU} / \mathrm{g}\right)$ & $35.3 \pm 2.7^{\mathrm{a}}$ & $30.6 \pm 1.5^{\mathrm{a}}$ & $15.4 \pm 1.3^{b}$ \\
\hline Mesenteric lymph node ( $\times 10^{3}$ CFU/organ) & $34.7 \pm 1.9^{\mathrm{a}}$ & $31.4 \pm 2.7^{\mathrm{a}}$ & $8.8 \pm 0.6^{b}$ \\
\hline Spleen ( $\times 10^{2}$ CFU/organ) & $172.1 \pm 8.8^{\mathrm{a}}$ & $165.3 \pm 11.2^{\mathrm{a}}$ & $10.5 \pm 0.9^{b}$ \\
\hline Liver ( $\times 10^{2}$ CFU/organ) & $80.6 \pm 7.6^{\mathrm{a}}$ & $75.4 \pm 2.9^{\mathrm{a}}$ & $9.6 \pm 0.7^{b}$ \\
\hline
\end{tabular}

Data are expressed as the mean $\pm \mathrm{SD}(n=3)$. Values in each row with the same letter are not significantly different between groups at $p<0.05$. BPRBE, bioprocessed rice bran extract; NPRBE, non-processed rice bran extract 
formulation could also inhibit the growth of cancer cells via autophagy.

\section{Conclusions}

Here we have described the evaluation of a potentialhealth-promoting functional food, a mushroom myceliarice bran formulation. The orally administered formulation inhibited the growth of Salmonella Typhimurium in infected mouse organs. We elucidated the mechanism by which the formulation seems to govern the destruction of the foodborne pathogenic microorganism Salmonella Typhimurium in mice. In addition, detailed experiments described here using macrophage cells have helped to define the biomarkers associated with bactericidal activity.

Our efforts to investigate the possible mechanism of the antibiotic effects shows that phagocytosis against Salmonella Typhimurium in the macrophage cells and bactericidal activity in mice is associated with an enhanced autophagic activity of the macrophages, leading to macrophage-mediated bactericidal action as well as to systemic bactericidal action through type 1 interferon production. This mechanism seems to govern the inactivation of bacteria and prostate cancer cells mentioned earlier. Whether autophagy also governs the inactivation of disease-causing protozoa by natural compounds $[46,47]$ merits study.

Because foodborne and medical bacteria often resist the action of conventional antibiotics [48], it would be of interest to determine if the antimicrobial formulations produced via bioprocessing also inhibit the growth of multidrug-resistant Salmonella and other foodborne pathogens in infected rodents, as we observed with a rice hull smoke extract [7]. It would also be useful to determine if BPRBE could kill both pathogenic bacteria and cancer cells by the autophagy process. Clinical trials are needed to confirm the beneficial results in infected humans. This study is expected to stimulate future studies to confirm the antimicrobial health benefits of the new food product in animal feeds, human foods, and in humans.

Finally, it is of theoretical and practical interest that unlike BPRBE, other natural antimicrobials including plant essential oil compounds, winery byproducts, shellfish-derived chitosans, tea compounds, and fruit and vegetable peel powders induce destruction of pathogens both in vitro and in vivo by mechanisms involving the disruption of cell membranes and chemical modification of essential proteins and DNA [49-56]. In future investigations, BPRBE could be combined with other natural antimicrobials to determine if they could neutralize pathogens in animal feeds, human foods, and in humans.

\section{Abbreviations}

ANOVA: Analysis of Variance; BPRBE: Bioprocessed Rice Bran Extract; BSA: Bovine Serum Albumin; CFU: Colony-Forming Units; ELISA: EnzymeLinked Immunosorbent Assay; FBS: Fetal Bovine Serum; GC/MS: Gas
Chromatography/Mass Spectrometry; HRP: Horseradish Peroxidase; IFN$\beta$ : Interferon Beta; iNOS: Inducible Nitric Oxide Synthase; IRF3: Interferon Regulatory Factor 3; mRNA: Messenger RNA; MSTFA: N-Methyl-NTrimethylsilyltrifluoroacetamide; MTT: 3-(4,5-Dimethylthiazol-2-yl)-2,5-Diphenyl Tetrazolium Bromide; NA: Nutrient Agar; NO: Nitric Oxide; NPRBE: NonBioprocessed Rice Bran Extract; PBS: Phosphate-Buffered Saline; PDA: Potato Dextrose Agar Medium; RT: retention times; TLR: Toll-Like Receptor

\section{Acknowledgements}

We thank Carol E. Levin for constructive contributions and for facilitating the preparation of the manuscript.

\section{Funding}

This work was supported by the Korean Institute of Planning and Evaluation for Technology in Food, Agricultural, Forestry and Fisheries (IPET) through Agri-Bio Industry Technology Development Program, funded by Ministry of Agriculture, Food and Rural Affairs (MAFRA) (no. 314019-3), and by the Korean Institute of Planning and Evaluation for Technology in Food, Agricultural, Forestry and Fisheries (IPET) through High Value-added Food Technology Development Program, funded by Ministry of Agriculture, Food and Rural Affairs (MAFRA) (no. 314076-3). The funding body had no role in the design of the study, collection, analysis, interpretation of data, and writing the manuscript.

\section{Availability of data and materials}

The datasets used and/or analyzed during the current study are available from the corresponding author on reasonable request.

\section{Author's contributions}

SPK, SJL, and SHN designed and carried out the experiments and prepared the tables, figures, and the experimental section. SHN and MF contributed to the design of the experiments and prepared the final draft of the manuscript. All authors approved the final manuscript.

\section{Authors' information}

Dr. Seok Hyun Nam is a professor at Ajou University. Dr. Mendel Friedman is a senior scientist at Western Regional Research Center.

\section{Ethics approval and consent to participate}

The protocol for the mouse studies was approved by the Ethics Committee for Animal Care and Use, Ajou University, Suwon, Republic of Korea.

\section{Consent for publication}

Not applicable.

\section{Competing interests}

The authors declare that they have no competing interests.

\section{Publisher's Note}

Springer Nature remains neutral with regard to jurisdictional claims in published maps and institutional affiliations.

\section{Author details \\ ${ }^{1}$ Research Institute of Basic Sciences, Ajou University, Suwon 16499, Republic of Korea. ${ }^{2}$ STR Biotech Ltd., Chuncheon 24232, Republic of Korea. \\ ${ }^{3}$ Department of Biological Science, Ajou University, Suwon 16499, Republic of Korea. ${ }^{4}$ Western Regional Research Center, Agricultural Research Service, U.S. Department of Agriculture, Albany, CA 94710, USA.}

Received: 19 January 2018 Accepted: 29 October 2018

Published online: 05 December 2018

\section{References}

1. Andrews HL, Bäumler AJ. Salmonella Species. In: Fratamico PM, Bhunia AK, Smith $J$, editors. Foodborne pathogens: microbiology and molecular biology. Norfolk: Caister Academic Press; 2005. p. 327-39.

2. Friedman M. Rice brans, rice bran oils, and rice hulls: composition, food and industrial uses, and bioactivities in humans, animals, and cells. J Agric Food Chem. 2013;61(45):10626-41. 
3. Friedman M. Chemistry, nutrition, and health-promoting properties of Hericium erinaceus (Lion's mane) mushroom fruiting bodies and mycelia and their bioactive compounds. J Agric Food Chem. 2015;63(32):7108-23.

4. Friedman M. Mushroom polysaccharides: chemistry and antiobesity, antidiabetes, anticancer, and antibiotic properties in cells, rodents, and humans. Foods. 2016;5(4):80.

5. Kim SP, Yang JY, Kang MY, Park JC, Nam SH, Friedman M. Composition of liquid rice hull smoke and anti-inflammatory effects in mice. J Agric Food Chem. 2011;59(9):4570-81.

6. Kim SP, Kang MY, Park JC, Nam SH, Friedman M. Rice hull smoke extract inactivates Salmonella typhimurium in laboratory media and protects infected mice against mortality. J Food Sci. 2012;77(1):M80-5.

7. Kim SP, Lee SJ, Nam SH, Friedman M. Mechanism of antibacterial activities of a rice hull smoke extract (RHSE) against multidrug-resistant Salmonella typhimurium in vitro and in mice. J Food Sci. 2018;83(2):440-5.

8. Yang JY, Kang MY, Nam SH, Friedman M. Antidiabetic effects of rice hull smoke extract in alloxan-induced diabetic mice. J Agric Food Chem. 2012; 60(1):87-94

9. Yang JY, Moon E, Nam SH, Friedman M. Antidiabetic effects of rice hull smoke extract on glucose-regulating mechanism in type 2 diabetic mice. J Agric Food Chem. 2012;60(30):7442-9.

10. Kim SP, Nam SH, Friedman M. Rice hull smoke extract protects mice against a Salmonella lipopolysaccharide-induced endotoxemia. J Agric Food Chem. 2014;62(31):7753-9.

11. Li W, Zhou W, Kim EJ, Shim SH, Kang HK, Kim YH. Isolation and identification of aromatic compounds in Lion's mane mushroom and their anticancer activities. Food Chem. 2015;170:336-42.

12. Choi SP, Kang MY, Koh HJ, Nam SH, Friedman M. Antiallergic activities of pigmented rice bran extracts in cell assays. J Food Sci. 2007;72(9):S719-26.

13. Choi SP, Kim SP, Kang MY, Nam SH, Friedman M. Protective effects of black rice bran against chemically-induced inflammation of mouse skin. J Agric Food Chem. 2010;58(18):10007-15.

14. Nam SH, Choi SP, Kang MY, Kozukue N, Friedman M. Antioxidative, antimutagenic, and anticarcinogenic activities of rice bran extracts in chemical and cell assays. J Agric Food Chem. 2005;53(3):816-22.

15. Nam SH, Choi SP, Kang MY, Koh HJ, Kozukue N, Friedman M. Bran extracts from pigmented rice seeds inhibit tumor promotion in lymphoblastoid B cells by phorbol ester. Food Chem Toxicol. 2005;43(5):741-5.

16. Kim SP, Kang MY, Nam SH, Friedman M. Dietary rice bran component Y- $^{-}$ oryzanol inhibits tumor growth in tumor-bearing mice. Mol Nutr Food Res. 2012;56(6):935-44.

17. Chen M-H, Choi SH, Kozukue N, Kim H-J, Friedman M. Growth-inhibitory effects of pigmented rice bran extracts and three red bran fractions against human cancer cells: relationships with composition and antioxidative activities. J Agric Food Chem. 2012;60(36):9151-61.

18. Choi SP, Kim SP, Nam SH, Friedman M. Antitumor effects of dietary black and brown rice brans in tumor-bearing mice: relationship to composition. Mol Nutr Food Res. 2013;57(3):390-400.

19. Kim SP, Park SO, Lee SJ, Nam SH, Friedman M. A polysaccharide isolated from the liquid culture of Lentinus edodes (shiitake) mushroom mycelia containing black rice bran protects mice against salmonellosis through upregulation of the Th1 immune reaction. J Agric Food Chem. 2014;62(11): 2384-91.

20. Kim SP, Lee SJ, Nam SH, Friedman M. Turmeric bioprocessed with mycelia from the shiitake culinary-medicinal mushroom Lentinus edodes (Agaricomycetes) protects mice against salmonellosis. Int J Med Mushrooms. 2017;19(4):363-76.

21. Kim SP, Park SO, Lee SJ, Nam SH, Friedman M. A polysaccharide isolated from the liquid culture of Lentinus edodes (shiitake) mushroom mycelia containing black rice bran protects mice against a Salmonella lipopolysaccharide-induced endotoxemia. J Agric Food Chem. 2013;61 (46):10987-94.

22. Kim SP, Lee SJ, Nam SH, Friedman M. Elm tree (Ulmus parvifolia) bark bioprocessed with mycelia of shiitake (Lentinus edodes) mushrooms in liquid culture: composition and mechanism of protection against allergic asthma in mice. J Agric Food Chem. 2016;64(4):773-84.

23. Kim SP, Moon E, Nam SH, Friedman M. Composition of Herba Pogostemonis water extract and protection of infected mice against Salmonella typhimurium-induced liver damage and mortality by stimulation of innate immune cells. J Agric Food Chem. 2012;60(49):12122-30.

24. U.S. Dept. Of commerce. NIST/EPA/NIH (NIST 05) mass spectral library. 7th ed. Washington D.C: Wiley; 2005.
25. Mosmann T. Rapid colorimetric assay for cellular growth and survival: application to proliferation and cytotoxicity assays. J Immunol Methods. 1983;65(1-2):55-63.

26. Murakami A, Gao G, Kim OK, Omura M, Yano M, Ito C, Furukawa H, Jiwajinda S, Koshimizu K, Ohigashi H. Identification of coumarins from the fruit of Citrus hystrix DC as inhibitors of nitric oxide generation in mouse macrophage raw 264.7 cells. J Agric Food Chem. 1999;47(1):333-9.

27. Kim SP, Moon E, Nam SH, Friedman M. Hericium erinaceus mushroom extracts protect infected mice against Salmonella typhimurium-induced liver damage and mortality by stimulation of innate immune cells. J Agric Food Chem. 2012;60(22):5590-6.

28. Lu S, Manges AR, Xu Y, Fang FC, Riley LW. Analysis of virulence of clinical isolates of Salmonella Enteritidis in vivo and in vitro. Infect Immun. 1999; 67(11):5651-7.

29. Barthel M, Hapfelmeier S, Quintanilla-Martínez L, Kremer M, Rohde M, Hogardt M, Pfeffer K, Rüssmann H, Hardt WD. Pretreatment of mice with streptomycin provides a Salmonella enterica serovar typhimurium colitis model that allows analysis of both pathogen and host. Infect Immun. 2003;71(5):2839-58.

30. Chomczynski P, Sacchi N. Single-step method of RNA isolation by acid guanidinium thiocyanate-phenol-chloroform extraction. Anal Biochem. 1987; 162(1):156-9.

31. Kim GS, Kim DH, Lim JJ, Lee JJ, Han DY, Lee WM, Jung WC, Min WG, Won $\mathrm{CG}$, Rhee $\mathrm{MH}$, et al. Biological and antibacterial activities of the natural herb Houttuynia cordata water extract against the intracellular bacterial pathogen Salmonella within the RAW 264.7 macrophage. Biol Pharm Bull. 2008;31(11): 2012-7.

32. Park SH, Kang MK, Choi YJ, Kim YH, Antika LD, Kim DY, Lee EJ, Lim SS. Kang YH. a-Asarone blocks $7 \beta$-hydroxycholesterol-exposed macrophage injury through blocking elF2a phosphorylation and prompting beclin-1dependent autophagy. Oncotarget. 2017;8(5):7370-83.

33. Owen KA, Anderson CJ, Casanova JE. Salmonella suppresses the TRIF-dependent type I interferon response in macrophages. mBio. 2016;7(1):e02051-15.

34. Liu M, Han T, Shi S, Chen E. Long noncoding RNA HAGLROS regulates cell apoptosis and autophagy in lipopolysaccharides-induced WI-38 cells via modulating miR-100/NF-kB axis. Biochem Biophys Res Commun. 2018; 500(3):589-96.

35. Hoang KV, Borteh HM, Rajaram MVS, Peine K, Curry H, Collier MA, Homsy ML, Bachelder EM, Gunn JS, Schlesinger LS, et al. Acetalated dextran encapsulated AR-12 as a host-directed therapy to control Salmonella infection. Int J Pharm. 2014;477(1):334-43.

36. Guo J, Cheng Y. MicroRNA-1247 inhibits lipopolysaccharides-induced acute pneumonia in A549 cells via targeting CC chemokine ligand 16. Biomed Pharmacother. 2018;104:60-8.

37. Rabelo MAE, Lucinda LMF, Reboredo MM, da Fonseca LMC, Reis FF, Fazza TF, Brega DR, de Paoli F, de Souza da Fonseca A, Pinheiro BV. Acute lung injury in response to intratracheal instillation of lipopolysaccharide in an animal model of emphysema induced by elastase. Inflammation. 2018:41(1):174-82.

38. Han D, Lee HT, Lee JB, Kim Y, Lee SJ, Yoon JW. A bioprocessed polysaccharide from Lentinus edodes mycelia cultures with turmeric protects chicks from a lethal challenge of Salmonella Gallinarum. J Food Prot. 2017; 80(2):245-50.

39. Yu HB, Croxen MA, Marchiando AM, Ferreira RB, Cadwell K, Foster LJ, Finlay BB. Autophagy facilitates Salmonella replication in HeLa cells. mBio. 2014; 5(2):e00865-14.

40. Liang Q, Seo GJ, Choi YJ, Kwak MJ, Ge J, Rodgers MA, Shi M, Leslie BJ, Hopfner KP, Ha T, et al. Crosstalk between the cGAS DNA sensor and Beclin1 autophagy protein shapes innate antimicrobial immune responses. Cell Host Microbe. 2014;15(2):228-38.

41. Kim J-J, Lee H-M, Shin D-M, Kim W, Yuk J-M, Jin Hyo S, Lee S-H, Cha G-H, Kim J-M, Lee Z-W, et al. Host cell autophagy activated by antibiotics is required for their effective antimycobacterial drug action. Cell Host Microbe. 2012;11(5):457-68.

42. Wang L, Yan J, Niu H, Huang R, Wu S. Autophagy and ubiquitination in Salmonella infection and the related inflammatory responses. Front Cell Infect Microbiol. 2018;8:78.

43. Bernal-Bayard J, Ramos-Morales F. Molecular mechanisms used by Salmonella to evade the immune system. Curr Issues Mol Biol. 2017;25:133-68.

44. Barakat DJ, Friedman AD. Autophagy is required for PTEN-loss driven prostate cancer. Transl Cancer Res. 2016;5:S725-9.

45. Nakahira K, Porras MAP, Choi AMK. Autophagy in pulmonary diseases. Am J Respir Crit Care Med. 2016;194(10):1196-207. 
46. Liu J, Kanetake S, Wu Y-H, Tam C, Cheng LW, Land KM, Friedman M. Antiprotozoal effects of the tomato tetrasaccharide glycoalkaloid tomatine and the aglycone tomatidine on mucosal trichomonads. J Agric Food Chem. 2016:64(46):8806-10

47. Noritake SM, Liu J, Kanetake S, Levin CE, Tam C, Cheng LW, Land KM, Friedman M. Phytochemical-rich foods inhibit the growth of pathogenic trichomonads. BMC Complement Altern Med. 2017;17(1):461.

48. Friedman M. Antibiotic-resistant bacteria: prevalence in food and inactivation by food-compatible compounds and plant extracts. J Agric Food Chem. 2015;63(15):3805-22.

49. Friedman M. Chemistry, antimicrobial mechanisms, and antibiotic activities of cinnamaldehyde against pathogenic bacteria in animal feeds and human foods. J Agric Food Chem. 2017;65(48):10406-23.

50. Friedman M. Antimicrobial activities of plant essential oils and their components against antibiotic-susceptible and antibiotic-resistant foodborne pathogens. In: Rai M, Zachino S, Derita MD, editors. Essential oils and nanotechnology for treatment of microbial diseases. Boca Raton. Florida: CRC Press; 2017. p. 14-38.

51. Friedman M. Chemistry and multi-beneficial bioactivities of carvacrol (4isopropyl-2-methylphenol), a component of essential oils produced by aromatic plants and spices. J Agric Food Chem. 2014;62(31):7652-70.

52. Friedman M. Antibacterial, antiviral, and antifungal properties of wines and winery byproducts in relation to their flavonoid content. J Agric Food Chem. 2014;62(26):6025-42.

53. Friedman M, Juneja VK. Review of antimicrobial and antioxidative activities of chitosans in food. J Food Prot. 2010;73(9):1737-61.

54. Juneja VK, Friedman M, Mohr TB, Silverman M, Mukhopadhyay S. Control of Bacillus cereus spore germination and outgrowth in cooked rice during chilling by nonorganic and organic apple, orange, and potato peel powders. J Food Process Preserv. 2018;42(3):e13558.

55. Friedman M, Henika PR, Levin CE, Mandrell RE, Kozukue N. Antimicrobial activities of tea catechins and theaflavins and tea extracts against Bacillus cereus. J Food Prot. 2006;69(2):354-61.

56. Friedman M. Overview of antibacterial, antitoxin, antiviral, and antifungal activities of tea flavonoids and teas. Mol Nutr Food Res. 2007:51(1):116-34.

Ready to submit your research? Choose BMC and benefit from:

- fast, convenient online submission

- thorough peer review by experienced researchers in your field

- rapid publication on acceptance

- support for research data, including large and complex data types

- gold Open Access which fosters wider collaboration and increased citations

- maximum visibility for your research: over $100 \mathrm{M}$ website views per year

At $\mathrm{BMC}$, research is always in progress.

Learn more biomedcentral.com/submissions 